\title{
Preservice Teachers' Self-Efficacy in Teaching Cost Accounting
}

\author{
Joseph Tufuor Kwarteng $(\mathbb{D}$ and Peter Sappor \\ Department of Business and Social Sciences Education, University of Cape Coast, Cape Coast, Ghana \\ Correspondence should be addressed to Joseph Tufuor Kwarteng; jtkwarteng@ucc.edu.gh
}

Received 21 October 2021; Accepted 9 November 2021; Published 26 November 2021

Academic Editor: Ehsan Namaziandost

Copyright ( $\odot 2021$ Joseph Tufuor Kwarteng and Peter Sappor. This is an open access article distributed under the Creative Commons Attribution License, which permits unrestricted use, distribution, and reproduction in any medium, provided the original work is properly cited.

\begin{abstract}
The study examined preservice teachers' self-efficacy in teaching cost accounting at the pretertiary level. It employed the descriptive cross-sectional survey design involving final year preservice accounting teachers at the University of Cape Coast. An adapted questionnaire referred to as Teacher Self-Efficacy and Mastery Experience Scale (TSEMES) was used to gather relevant data complemented by the academic records of the respondents to address the problem. The return rate of the instrument was 93\%. Descriptive (frequencies, percentages, means, and standard deviation) and inferential statistics (simple linear regression) were used to analyse the data. The study found out that preservice accounting teachers were highly efficacious in classroom management compared to student engagement and instructional practices. Also, mastery experience had a positive influence on preservice accounting teachers' self-efficacy in teaching cost accounting. Therefore, it was recommended that accounting teacher educators pay more attention to competencies related to instructional strategies and student engagement by engaging more with the preservice accounting teachers in these areas. In the deployment of teachers, the Ghana Education Service should prioritise preservice accounting teachers with higher academic achievement.
\end{abstract}

\section{Introduction}

There is a generally held belief that the goal of teaching will not be met if there are no competent teachers with the required abilities and pedagogical skills to teach [1]. Several issues come to play about teachers' ability to teach a particular course. These could be pooled into school-related [2-4] and/or teacher-related [4-6] factors. The teacher is indispensable in the instructional procedure; therefore, the attributes of a teacher do not only influence curriculum implementation but students' learning outcomes to a large extent, making teacher-related factors paramount $[7,8]$. Teacher-related factors could be internal (psychological) and external [9-12]. As noted by Ruble and McGrew [13], the internal factor as an unobserved behaviour is less understood but equally important teacher behaviour, which could affect teacher's total delivery. As a key internal factor, selfefficacy had been found to influence the ability and efficiency of teaching in general [14-17]. This is premised on the view that teachers' belief in their abilities translates to students' learning. This is reinforced by Jeon [18], who rated self- efficacy highest among all other factors that influence teaching.

Self-efficacy, which is an essential concept, has a pronounced influence on teachers' motivation and personal achievements (Gorozidis and Papaioannou as cited in [19]). Teachers with low self-efficacy tend to have poor self-esteem and negative thought about their ability to accomplish tasks [19]. Though self-efficacy is more of a motivational concept focused on competency belief rather than the level of real competency [20], teachers' level of self-efficacy can affect their motivation to teach. Bandura [21] claimed that teachers would be hesitant to accept assignments, which they view as difficult. As a result, teachers' self-efficacy may profoundly impact the effective implementation of instructional strategies, class control, and students' engagement. Social cognitive theory [22] outlines mastery as perhaps the most influential source of efficacy beliefs. In corroborating this theoretical position, Bandura [23] claims that their mastery experience predicts teachers' sense of efficacy belief. This implies that the extent to which a teacher has been well immersed in the skill of teaching and knowledge of the 
subject matter, in particular, is perennially connected to a teacher's belief to be self-efficacious. Several studies have explored this linkage with respect to various subjects and have documented varying findings. For instance, Yates [24] study concluded that mathematics teachers were self-efficacious in teaching all mathematics topics. By extension, Pantziara and Philippou [25] found that students' interest and performance in mathematics were influenced by selfefficacy, among other things. However, Blonder, Benny, and Jones [26] observed that science teachers' educational experiences can influence their teaching self-efficacy beliefs. A total difference was found by Ntarmah, Gyan, Gyedu, and Cobbinah [27] that mastery experiences had the strongest and most positive predictive power of the efficacy beliefs of economics teachers. These varying findings among different subject teachers give credence to Ross, Cousins, and Gadella's [28] argument that teachers' self-efficacy depends upon the subject they teach.

Despite having the required knowledge about the subject, teachers who were expected to implement senior high school cost accounting curriculum in Ghana were ill-prepared to do so [29]. Theorising premised on Tweed's [19] position that teacher self-efficacy greatly influences their motivation; it could be said that cost accounting teachers had low self-efficacy belief to teach the subject. After all, teachers' self-worth in the face of the teaching task greatly impacts their ability to deliver on the job [19]. Accordingly, teachers with low self-efficacy have poor self-esteem and negative thoughts about accomplishing tasks [19]. Therefore, to fully understand Kwarteng's finding that teachers were illprepared to teach cost accounting, pertinent questions will be raised, such as how do cost accounting teachers consider their self-worth in the face of the job at hand? How does the training of cost accounting teachers improve their self-efficacy? Timely diagnosis of the problem is necessary to ensure that appropriate interventions are implemented before such teachers are certified, hence the concentration on preservice teachers. This is because cost accounting is an integral part of the business. Learning it offers students the opportunity to develop cost-consciousness to promote sound decision-making. Its strategic role in advancing the goals of organisations has seen the development of new concepts to promote decision-making and cost-consciousness at all levels of the management hierarchy [1], the success of which is contingent on the effective teaching of the subject especially at the foundational level.

Boateng and Sekyere [30], Cobbold and Boateng [31], and Siaw-Marfo [32] were among the numerous scholars who studied the self-efficacy of teachers. Their studies were based on some of the constructs in the teacher efficacy model developed by Tschannen-Moran and Hoy [33] without considering all the elements in the model at a go. Cobbold and Boateng $[31,34]$ considered instructional strategies and classroom management in separate studies, while Boateng and Sekyere [30] also concentrated on student engagement. Even though there have been studies on teachers' self-efficacy in numerous subject areas, the uniqueness of cost accounting, such as the underlying assumptions, techniques employed for analysis, presentation formats, and the consequential teaching strategies and plans, makes it impossible to adapt such findings. Therefore, this uniqueness may result in different results of self-efficacy level of teachers, evidence of which is not readily available. It, therefore, became expedient to fill the void in the literature by assessing the self-efficacy of preservice teachers in teaching cost accounting.

The study contributes to the extant literature in several ways. Since all the dimensions of self-efficacy are used, the study provides comprehensive insights into preservice teachers' self-efficacy in teaching cost accounting to generate cogent results for better appreciation. Also, it would provide a credible confirmation about conclusions reached on mastery experience as a key source of teacher self-efficacy to the teacher after controlling for the effect of known demographic variables, known for their possible effect on teachers' mastery experience. This would increase the robustness of the results and thus significantly contributes to the discourse on sources of teacher self-efficacy to teach.

The rest of the paper is structured as follows. The conceptual framework that underpins the study is presented and the various components are discussed. This is followed by a review of relevant empirical studies to illuminate knowledge accumulated on teacher self-efficacy. The method employed in executing the study is presented. The population, sample and how they were recruited, instrumentation, data collection procedure, and data analysis techniques are detailed. Results obtained following the data collected and discussion of it are presented. The final part of the paper showcases the conclusions drawn from the findings.

1.1. Conceptual Underpinning of the Study. The study adapted the Teacher Self-Efficacy Scale (TSES) developed by Tschannen-Moran and Hoy [33] for guidance. The scale measures teachers' self-efficacy by assigning scores to three different dimensions (i.e., classroom management, instructional strategies, and students' engagement) of teacher self-efficacy. In addition, the study relied on Bandura's [23] recommendation on how teachers' mastery experience tend to influence their self-efficacy. Based on this, a conceptual model was designed to guide the paper. Figure 1 illustrates the level of teacher self-efficacy based on their classroom management, instructional strategies, and student's engagement and articulates the effects of mastery experience on preservice teachers' level of self-efficacy. The framework suggests that, for teachers to be labelled as efficacious, they should have an appreciable measure of all the three dimensions of self-efficacy.

1.2. Efficacy of Instructional Strategies. Among the three dimensions of Teacher Self-Efficacy (TSE), the instructional strategies dimension appears to be the less researched area [33]. The least conceptualised and researched is the selfefficacy of instructional strategies. The efficacy of teachers' instructional strategies refers to the expectations of teachers that they should perform instructional activities such as adjusting material to student needs, interviewing students, 


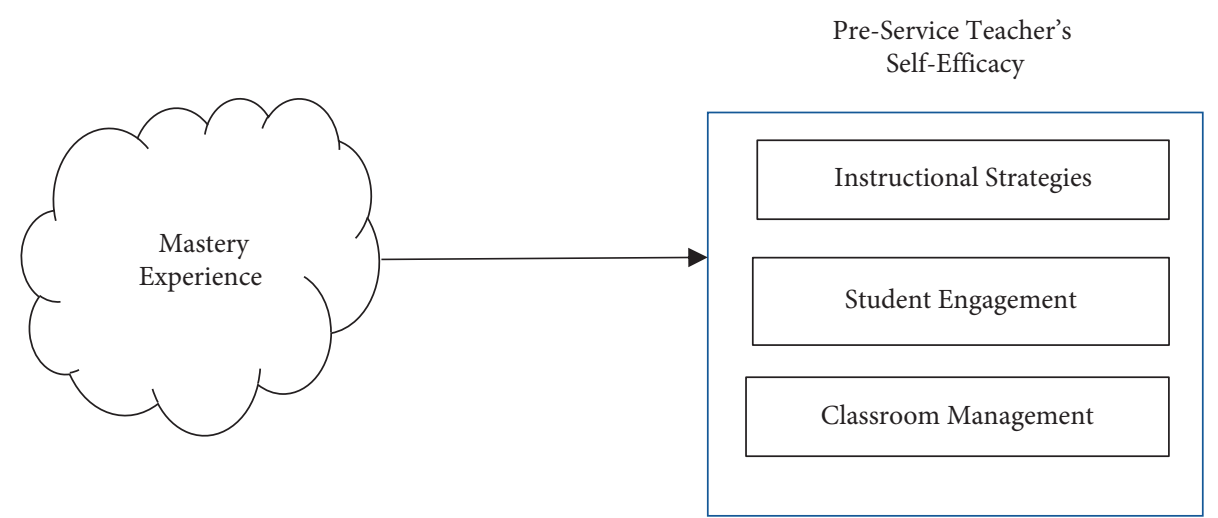

Figure 1: Conceptual framework of the study (source: adapted from Tschannen-Moran and Hoy [33] and Bandura [23]).

and effectively evaluating student performance [33]. There have been several studies conducted on the measure of teachers' self-efficacy in teaching various subjects.

Elaborate research findings have been ascertained by AlAlwan and Mahasneh [35]. They collected data on efficacy in instructional strategies from 679 teachers and 1,820 students at primary and secondary schools in Jordan out of which they established that the convictions of teachers in their ability to teach students and affect the success of students are very good measures of effectiveness in teaching. Also, teachers with a good sense of efficacy "exhibit high levels of preparation, management, coordination, are open to innovative ideas and are more likely to experiment with new approaches to better serve the needs of their students" ([35], p. 176).

1.3. Efficacy of Student Engagement. Literature has indicated that teacher self-efficacy is usually counted as part of the conceptualisation techniques used by teachers to encourage individual students to enjoy learning or believe that they can do well in a given class and hence responsible for their learning [33]. Blazevski [36] opined that the teacher selfefficacy of student engagement reflects teachers' expectations as moderators of the class. They can empower students efficiently, involve parents, and help students appreciate learning. The confidence level of teachers in teaching their subject matter can be a motivating factor that empowers them to affect the academic and cognitive progress of the students [23].

The negative effects of student disengagement, including academic failure, delinquency, and dropout, have led many researchers to investigate whether individual psychological factors that promote engagement can be promoted [37]. The Teacher Self-Efficacy Scale production was the first attempt to capture the construct of student motivation and commitment. Students who feel more secure in their ability to self-regulate their learning are also more likely to have realistic outcome expectations, respect the learning process, set master's goals, and take responsibility for their academic outcomes (e.g., [38-42]). All these are important aspects of interaction with the students. In addition, students who feel more effective in using self-regulated learning strategies are less likely to hold negative expectations of school, set success (as opposed to mastery) targets, procrastinate, or become nervous in threatening academic circumstances relative to their peers with lower Self-Efficacy for Self-Regulated Learning beliefs (e.g., [40, 41, 43-46]).

1.4. Efficacy of Classroom Management. The term classroom management refers to the capacity of a teacher to keep order in the classroom, involve students in learning, and seek the participation of students in all classroom activities [47] as cited in [48]. It is the responsibility of the teacher to control students' behaviour in the classroom and coordinate their learning experiences for students to attain positive academic excellence. Dustova and Cotton [48] alerted that the ultimate goals of efficacious classroom management are the ability of teachers to have a balanced, secure learning atmosphere and equip students with the requisite skills to be academically and socially effective in life. Over the past years, classroom management has become ever more relevant. The explanation is that effective teaching and learning in our schools cannot occur without good classroom management [49]. If one cannot handle a classroom, one cannot be sure that the students are absorbing the content. Poor management of classrooms can contribute to increased rates of school violence and bullying [50], as well as increased levels of teacher tension, increased probability of teacher burnout, and higher levels of teacher turnover [51]. There have been several studies conducted on the aforementioned. The succeeding paragraphs explain the stances of those studies reviewed.

1.5. Effect of Mastery Service on Teacher Self-Efficacy. The most important source of knowledge on efficacy is mastery experience which is often referred to as enactive experience. The belief that performance has been effective increases convictions of effectiveness, which leads to potential expectations of competent performance. Mastery experience is acquired from the successful execution of one's tasks. For teacher effectiveness, teachers who displayed excellence in their teaching output appeared to show high teacher efficacy rates $[52,53]$. Consequently, the effects of failure on one's self-efficacy depend partly on the nature and overall sequence of interactions in which the failures occur. This 
attack on effectiveness is probable when the failure occurs early in the learning process and cannot be due to a lack of effort or circumstances outside the control of the individual $[22,23]$. All four factors mentioned by Bandura affect the self-perception of teaching competence. Still, it is most strongly affected by the mastering experiences and the physiological excitement associated with those experiences. Only in an actual teaching situation will a person evaluate the abilities he or she brings to the task and experience the effect of those abilities. In actual teaching situations, teachers gain information on how their strengths and weaknesses play out in the management, instruction, and evaluation of students. For example, one may discover that excitement is an advantage when dealing with a group of active children but is not sufficient to compensate for lack of coordination or preparation. There have been several studies conducted on the aforementioned.

1.6. Evidence from Empirical Studies. Chacon [54] assessed the self-efficacy beliefs of English as a Foreign Language (EFL) teachers using the TSES and found that teachers' efficacy of instructional strategies $(M=7.13)$ was high. In a similar study, Gürbüztürk and Şad [55] investigated studentteachers traditional and constructivist educational beliefs and their sense of self-efficacy. It was revealed from the study that student teachers had a higher self-efficacy in instructional strategies relative to self-efficacy in classroom management and student engagement. Shaukat and Iqbal [56] also conducted a study involving teachers from four public schools in Lahore using the TSES. It was found that teachers were highly efficacious in instructional strategies followed by student engagement and classroom management, respectively.

For instance, Pendergast, Garvis, and Keogh [57] study on preservice teachers' self-efficacy at the Griffith University revealed that preservice teachers were highly productive in student engagement $(M=7.42)$, accompanied by classroom management $(M=7.41)$ and instructional strategy $(M=7.36)$ according to the findings made by this study. The overall teacher efficacy was relatively high $(M=7.40)$. In the same vein, Sevimel and Subasi [58] studied the factors affecting teacher efficacy perceptions of Turkish Preservice English Language teachers. In the highest to the lowest order, the respondents felt they were efficacious in classroom management, instructional strategies, and student engagement.

Sarfo et al. [59] studied the relationship between gender and self-efficacy beliefs in instructional strategies, classroom management, and student engagement among senior high school teachers. It was revealed that generally, teachers scored the highest on the student engagement aspect, followed by the classroom management aspect and the lowest being instructional strategies. Boateng and Sekyere [30] explored the effectiveness beliefs of in-service teachers in engaging with pupils and concluded that kindergarten teachers in the Kumasi Metropolis of Ghana have high efficacy beliefs in pupils' engagement. Klassen and Chiu [60] rather found practising teachers to have scored relatively high in their classroom management self-efficacy $(M=7.56)$, followed closely by instructional strategies self-efficacy $(M=7.55)$ and student engagement self-efficacy $(M=6.87)$. Similarly, Cobbold and Boateng [31] found kindergarten teachers in Ghana to have high efficacy beliefs in classroom management $(M=4.23, \mathrm{SD}=1.234)$.

Among preservice teachers, research evidence points to varying degrees of efficacy within the subscales of the SelfEfficacy model. For instance, Yiboe's [61] study suggested that preservice management teachers have a lower sense of efficacy in student engagement $(M=3.37)$ relative to instructional strategies $(M=3.55)$ and classroom management $(M=3.57)$. In contrast, Sak [62] found in the study of 451 Turkish preservice teachers they were highly efficacious in classroom management, followed by student engagement and instructional strategies, respectively. Mcneely and Mertz's [63] analysis of the actions of 11 high school teachers in a wide variety of subject fields found that throughout the initial stage of the course, preservice teachers who had a strong sense of self-efficacy were thorough planners and used a range of exercises in each class; yet by the end of their teaching experience, they saw their students as their enemies, concentrated on managing student actions, and taught lessons that allowed the teacher to be in full control [63]. High self-efficacy has been found to promote positive behaviours and practices in teachers, but if teachers lack management skills, an effective classroom may be replaced by a dictatorship.

Bandura's hypothesis that their mastery experience predicts teachers' sense of efficacy belief has been subjected to validation. Avalanche of research evidence that all support the validity of this hypothesis exists. For instance, Wah's [64] investigation on the major sources of influence on preservice teachers' self-efficacy and their relative strength in teacher self-efficacy predictions revealed mastery experience, physiological excitement, and verbal persuasion as key sources. The results of the final regression model revealed that $52 \%$ of the variance in teacher self-efficacy was explained by the combined effect of all predictor variables. Findings by Wangeri and Otanga [65] corroborated that verbal persuasion and mastery experience predicted personal teacher efficacy. Again, Joet, Usher, and Bressoux [66] assessed the impact of Bandura's [23] theorised origins of self-efficacy on the academic and self-regulatory beliefs of 395 elementary school students in France, investigating whether a substantial portion of the variance in self-efficacy could be explained in the context of the classroom, and evaluating whether these origins vary as a function of gender. Hierarchical linear modelling showed that the selfefficacy of mathematics teachers was predicted by mastery practice, social persuasions, and mean self-efficacy at the classroom level. French auto-efficacy projected mastery practice, social persuasions, physiological state, and mean self-efficacy at the classroom level. Further, Arslan [67] investigated the predictive power of the sources of self-efficacy of prospective teachers on their teaching self-efficacy and attitude towards the teaching profession and concluded that emotional states, mastery experience, and verbal persuasion were important predictors of self-efficacy teaching 
by prospective teachers and attitudes towards teaching profession. Ntarmah, Gyan, Gyedu, and Cobbinah [27] found mastery experiences to have the strongest and most positive predictive power of the efficacy beliefs of economics teachers in implementing the SHS Economics curriculum, but such predictive power is not significant under the prevailing teacher features of SHS Economics teachers in the region.

In sum, it can be concluded that even though there are other sources of teacher sense of efficacy belief, literature signals the paramountcy of mastery experiences. Therefore, it is taken for granted that the key source of teacher sense of efficacy belief is the mastery experience of the skill of teaching and particularly the subject matter. Accordingly, the study addressed two important objectives by

(1) Examining preservice teachers' self-efficacy in teaching cost accounting

(2) Investigating the influence of mastery experience on preservice teachers' self-efficacy teaching cost accounting

\section{Method}

2.1. Design. The cross-sectional survey design was employed in executing the study. It involved studying and gathering data from and about preservice accounting teachers in the University of Cape Coast to measure the self-efficacy in delivering senior cost accounting courses. This study took place in an uncontrolled environment where preservice accounting teachers responded freely and willingly to the survey without any manipulations.

2.2. Participants. Nearness to completion of the teacher education programme was a crucial requirement in selecting the respondents. This was to ensure that the most relevant respondents who probably would have almost the full complement of the teacher training experiences were obtained to provide the data needed. Therefore, final year preservice accounting teachers in the university in the 2019-2020 academic year were deemed appropriate respondents for the study. They were made up of 150 in all who were distributed between 107 male and 43 female. They were all involved in the study because the population was manageable, and the use of the entire population prevented the risk of sampling errors [68].

2.3. Instrumentation. The study employed both primary and secondary data. The TSES by Tschannen-Moran and Hoy [33] and Mastery Experience Sub-Scale (MES) of the Sources of Efficacy by Usher and Pajares [69] were adapted and used in the collection of the data from the respondents. TSES is a standardised questionnaire designed to measure people's evaluation of their likely success in the teaching under the subscales of instructional strategies, student engagement, and classroom management, while the MES was designed to measure self-efficacy related to academic achievements. The Teacher Self-Efficacy and Mastery Experience Sub-Scale adapted in this study are referred to as Teacher Self-Efficacy and Mastery Experience Scale (TSEMES). The primary data was gathered from the responding final year preservice accounting teachers using the Teacher Self-Efficacy and Mastery Experience Scale (TSEMES). The TSEMES was presented in five sections (A-E). Section A gathered data related to respondents' demographic characteristics while Sections B, C, D, and E gathered data related to respondents' self-efficacy in instructional strategies, student engagement, classroom management, and mastery experience, respectively. The secondary data collected was in the form of respondents' academic achievement in cost accounting. This data was obtained from the cost accounting lecturer. It was used together with the items in Section E of the questionnaire to ascertain the respondents' mastery experience to investigate the link between mastery experience and preservice teachers' self-efficacy in teaching cost accounting.

Thirty final year preservice accounting teachers from the University of Education, Winneba, were recruited for the pilot test. The reliability of the instrument was estimated through the Cronbach alpha statistic. According to Fraenkel and Wallen [70], a reliability coefficient of 7 or better is acceptable. In support of this assertion, Abington-Cooper [71] emphasised that such a reliability coefficient is good and the instrument can be judged to collect useful data. After the piloting, a reliability coefficient of 0.896 was obtained for Section B, 0.854 for Section C, 0.940 for Section D, and 0.768 for Section E. Therefore, the alpha value of $0.952(n=30)$ obtained for the TSEMES was judged to be reliable and acceptable for gathering useful data for the study and no item on the TSEMES was modified after the pilot test. After collecting the actual data, Cronbach's alpha was again computed to determine the instrument's reliability for the actual data gathered. Details of the subscales' Cronbach's alpha are presented in Table 1.

2.4. Data Collection Procedures. Prior to the data collection, ethical clearance was obtained from the Institutional Review Board (IRB) of the University of Cape Coast. Permission was sought from the Department of Business and Social Sciences Education, University of Cape Coast, whose students were used in the study. The Department, in turn, issued the researchers an introductory letter to solicit cooperation and to create a rapport with the respondents.

The sampled respondents were reached after one of their lectures, where the purpose of the study was explained to them. They were assured that their responses would be kept confidential and used strictly for academic purposes and were given the opportunity to opt-out from the process. The researchers personally administered a total of 140 questionnaires to guide respondents to understand exactly what the items meant so as to obtain the right responses. After a week, they returned the completed instruments through the class representative, and the return rate was $93 \%$.

2.5. Data Analysis. Descriptive (means and standard deviation) and inferential statistics (linear regression) were used to analyse the data. A mean value ranging from 1.00 to 2.49 
TABLE 1: Reliability coefficients of subscales on questionnaire.

\begin{tabular}{lcc}
\hline Subscale & Number of items & \multicolumn{2}{c}{ Reliability coefficient $(\alpha)$} \\
Pilot test & Actual study \\
\hline Preservice teachers' level of self-efficacy in instructional strategies & 9 & 0.896 \\
Preservice teachers' level of self-efficacy in student engagement & 8 & 0.893 \\
Preservice teachers' level of self-efficacy in classroom management & 8 & 0.854 \\
Influence of mastery experience on preservice teachers' level of self-efficacy & 5 & 0.940 \\
Reliability coefficient & 30 & 0.768 \\
\hline
\end{tabular}

Source: Field Data, 2020.

TABle 2: Preservice accounting teachers' self-efficacy in instructional strategies in teaching cost accounting.

\begin{tabular}{|c|c|c|c|c|}
\hline Statement & $N$ & Mean & $\begin{array}{c}\text { Std. } \\
\text { deviation }\end{array}$ & Rank \\
\hline I have sufficient knowledge in cost accounting & 140 & 4.11 & 0.78 & 1 \\
\hline $\begin{array}{l}\text { I can provide an alternative explanation or example when students are confused during cost accounting } \\
\text { lessons }\end{array}$ & 140 & 4.10 & 0.78 & 2 \\
\hline I can craft good questions for my students & 140 & 4.03 & 0.74 & 3 \\
\hline I can gauge student comprehension of what I have taught & 140 & 4.02 & 0.72 & 4 \\
\hline I can implement alternative strategies in my classroom while teaching cost accounting & 140 & 3.94 & 0.75 & 5 \\
\hline I can adjust cost accounting lessons to the proper level for individual students & 140 & 3.92 & 0.78 & 6 \\
\hline I can provide appropriate challenges for very capable students & 140 & 3.91 & 0.74 & 7 \\
\hline I can respond to difficult questions from my students & 140 & 3.84 & 0.88 & 8 \\
\hline I can use a variety of assessment strategies in assessing cost accounting & 140 & 3.81 & 0.80 & 9 \\
\hline Mean of means/average SD & 140 & 3.96 & 0.77 & \\
\hline
\end{tabular}

indicates a low level of self-efficacy, a mean value ranging from 2.50 to 3.49 indicates a moderate level of self-efficacy, while a mean value ranging from 3.50 to 5.00 indicates a high level of self-efficacy in instructional strategies, student engagement, and classroom management. The standard deviations provided additional information on the dispersion of the responses as gathered on the field. It represented the homogeneity or heterogeneity of respondents' answers provided. A standard deviation below 1.00 depicts homogeneity in the responses given, and a standard deviation more than 1.00 shows the heterogeneity in the responses [72]. It can therefore be inferred that a standard deviation closer to 0.00 depicts homogeneity in the responses given.

\section{Results}

The initial analysis sought to assess the level of preservice teachers' self-efficacy in teaching cost accounting. This was achieved using descriptive statistics of the respondents' response to items in Sections B, C, and D. Tables 2 to 4 present the results obtained on preservice teachers' selfefficacy cost accounting in relation to instructional strategies, student engagement, and classroom management.

The preservice accounting teachers had a high level of selfefficacy in instructional strategies $(M=3.96)$. They rated themselves to be effective on all the nine measures of teacher selfefficacy in instructional strategies. This simply means that preservice accounting teachers who were studied were highly efficacious in cost accounting instructional strategies. They were homogeneous $(S D=0.77)$ in their self-assessment of their level of efficacy in instructional strategies. Therefore, they believed in their abilities and skills to employ the right instructional strategies to effectively deliver cost accounting lessons.
From the results generated, it was evident from Table 3 that preservice accounting teachers had a high level of efficacy in student engagement $(M=4.02)$. They appraised themselves to be efficient in all the eight measures of teacher self-efficacy in student engagement. This shows that preservice accounting teachers who were considered in the study possess high efficacy in student engagement in cost accounting lessons. They consistently assessed their self-belief in possessing the right skill in engaging their students $(S D=0.75)$. This means the majority of the respondents agreed on a similar statement indicating their belief in possessing the right skill in engaging students, which tends to promote effective teaching of cost accounting lessons.

Considering the findings, there was a clear indication that the preservice accounting teachers' efficacy in classroom management was high $(M=4.19, \mathrm{SD}=0.65)$. They assessed themselves to be effective in all the eight indicators of teacher self-efficacy in classroom management. This shows that the preservice accounting teachers who were considered in the study possess high efficacy in classroom management in cost accounting lessons. They were homogeneous in their self-assessment of their level of efficacy in classroom management $(S D=0.65)$. It showed that preservice accounting teachers believed in themselves in possessing the right skill in managing students' classroom behaviour during cost accounting lessons.

The study investigated the influence of mastery experience on preservice teachers' self-efficacy in teaching cost accounting using regression analysis. The results obtained have been presented in Table 5. 
TABLe 3: Preservice accounting teachers' self-efficacy in student engagement in teaching cost accounting.

\begin{tabular}{|c|c|c|c|c|}
\hline Statement & $N$ & Mean & Std. deviation & Rank \\
\hline I can get students to believe they can do well in cost accounting & 140 & 4.37 & 0.69 & 1 \\
\hline I can help my students value learning cost accounting & 140 & 4.28 & 0.70 & 2 \\
\hline I can motivate students who show low interest in cost accounting & 140 & 4.13 & 0.88 & 3 \\
\hline I can improve the understanding of a student who is failing cost accounting & 140 & 3.99 & 0.71 & 4 \\
\hline I can help my students think critically in cost accounting & 140 & 3.99 & 0.65 & 5 \\
\hline I can foster student creativity & 140 & 3.92 & 0.69 & 6 \\
\hline I can assist families in helping their children do well in cost accounting & 140 & 3.73 & 0.81 & 7 \\
\hline I can get through to the most difficult students & 140 & 3.72 & 0.83 & 8 \\
\hline Mean of means/average SD & 140 & 4.02 & 0.75 & \\
\hline
\end{tabular}

Table 5 presents the results of the simple regression analysis between preservice accounting teachers' mastery experience and their level of self-efficacy. The simple regression analysis results show a relationship of $53.9 \%$ between the independent variables and the level of self-efficacy $(R=0.539)$. Again, $29.0 \%$ of their self-efficacy is explained by the independent variables that included level of mastery experience as the only significant predictor $\left(R^{2}=0.290\right)$. The control variables (sex and teaching history) had no significant effect in the model. The constant of the regression model was 3.083, which indicates that even if preservice accounting teachers' mastery experience is held constant or held at zero, their self-efficacy would still be 3.083 . This value was statistically significant at $5 \%$ alpha level. The coefficient of mastery experience was 0.018 , representing the effect of mastery experience on teacher self-efficacy. The estimated positive sign implies that such effect of mastery experience on teacher self-efficacy was positive and that teacher efficacy would improve by $1.8 \%$ for every increase in mastery experience. This implies that if preservice accounting teachers' mastery experience improves significantly, their self-efficacy increases positively. This value was statistically significant at $5 \%$ alpha level.

Key findings are given as follows:

(1) Preservice accounting teachers were highly efficacious in classroom management, student engagement, and instructional practices in teaching cost accounting. However, they were more efficacious in classroom management than student engagement and instructional practices in teaching cost accounting.

(2) Mastery experience had a positive influence on preservice accounting teachers' self-efficacy in teaching cost accounting.

\section{Discussions}

4.1. Preservice Teachers' Self-Efficacy in Instructional Strategies, Student Engagement, and Classroom Management in Teaching Cost Accounting. The study indicated that preservice accounting teachers possess a high level of self-efficacy in instructional strategies, student engagement, and classroom management in cost accounting lessons, however, at different levels. They were highly efficacious in classroom management compared to student engagement and instructional strategies, which supports the findings of other researchers. Baker [73], Cobbold and Boateng [31], Klassen and Chiu [60], Mcneely and Mertz [63], and Sak [62] revealed that preservice teachers are more competent in executing roles assigned to classroom management better than the other measures. This indicates that preservice accounting teachers effectively manage the general environmental and educational variables that facilitate clear set-up, structure, expectations, and feedback procedures across the classroom [74]. Preservice accounting teachers, therefore, do not have any challenge with classroom management as poor management of classrooms can contribute to increased rates of school violence and bullying [50], as well as increased levels of teacher tension, increased probability of teacher burnout, and higher levels of teacher turnover [51].

Contrary to this finding, Chacon [54], Gürbüztürk and Şad [55], and Epstein and Willhite [75] revealed that preservice teachers possess higher self-efficacy in instructional strategies as compared to classroom management and student engagement. They were clear to say preservice teachers tend to execute the right instructional strategies in cost accounting lessons compared to the other measures highlighted. Pendergast, Garvis, and Keogh [57] and Sarfo, Amankwah, Sam, and Konin [59] also indicated that preservice teachers have higher competencies in engaging their students as student engagement as the highest self-efficacy conceptualised.

The ratings of preservice accounting teachers on their level of self-efficacy were higher than other studies reviewed. This may be due to the fact that the preservice accounting teachers in the present study overestimated their actual level of competence since self-efficacy has to do with self-perception of competence rather than the actual level of competence [76]. Again, according to Pendergast et al. [57], preservice teachers are fond of estimating higher efficacy beliefs about themselves since they have not had any official practical teaching experience. This is so because, in their study, preservice teachers' efficacy reduced after the preservice teachers had the chance to experience practical teaching. Gürbüztürk and Şad [70] also held a similar view. They asserted that future teachers believe they are professionally sufficient because they embrace more studentcentred approaches to engagement, management, and instructional strategies. The general indication is that most individuals tend to believe in their ability to accomplish a task even when they have not had the chance to experience 
TABle 4: Preservice accounting teachers' self-efficacy in classroom management in teaching cost accounting.

\begin{tabular}{|c|c|c|c|c|}
\hline Statement & $N$ & Mean & Std. deviation & Rank \\
\hline I can get my students to follow classroom rules & 140 & 4.36 & 0.64 & 1 \\
\hline I can calm a student who is disruptive or noisy during cost accounting lessons & 140 & 4.30 & 0.65 & 2 \\
\hline I can establish a classroom management system with each group of students & 140 & 4.24 & 0.64 & 3 \\
\hline I can control disruptive behaviour in the classroom during cost accounting lessons & 140 & 4.24 & 0.57 & 4 \\
\hline I can establish routines to keep cost accounting activities running smoothly & 140 & 4.24 & 0.63 & 5 \\
\hline I can make expectations clear about student behaviour & 140 & 4.14 & 0.67 & 6 \\
\hline I can respond to defiant student & 140 & 4.05 & 0.65 & 7 \\
\hline I can keep a few problem students from ruining an entire cost accounting lesson & 140 & 3.98 & 0.75 & 8 \\
\hline Mean of means/average SD & 140 & 4.19 & 0.65 & \\
\hline
\end{tabular}

TABLE 5: Influence of mastery experience on preservice accounting teachers' self-efficacy.

\begin{tabular}{|c|c|c|c|c|c|}
\hline Variables & $B$ & SE & Beta & $T$ & $p$ value \\
\hline Constant & 3.083 & 0.240 & & 12.832 & 0.000 \\
\hline Mastery experience & 0.018 & 0.003 & 0.499 & 6.683 & 0.000 \\
\hline Sex & -0.127 & 0.074 & -0.125 & -0.1719 & 0.088 \\
\hline Teaching history & -0.079 & 0.067 & -0.085 & -0.1176 & 0.242 \\
\hline \multicolumn{6}{|c|}{$F(139)=18.558, P<0.01, R$-value $=0.539, R^{2}=0.290$, adjusted $R^{2}=0.275$, Durbin-Watson $=1.842$} \\
\hline
\end{tabular}

Regression model: preservice accounting teacher self-efficacy $=(0.018 \times$ academic achievement $)+2.754$.

the act. Contrary to this revelation, Mertler [77] and Cheung [78] indicated that teacher efficacy increases with teaching experience. They opined that preservice accounting teachers are likely to rate themselves quite low in their efficacy belief from the onset.

\subsection{Influence of Mastery Experience on Preservice} Accounting Teachers' Self-Efficacy. Mastery experience was rated to have a very high influence on teacher self-efficacy. This is confirmed by earlier studies [27, 64, 67, 79]. All these studies revealed that mastery experience influenced teacher efficacy belief, just that the degree of influence was quite different. Wah [64] revealed that mastery experience significantly influenced $36.7 \%$ on teacher efficacy belief. Wangeri and Otanga [65] also indicated that mastery experience accounted for $10.1 \%$ of the variance in teacher efficacy and was a significant predictor $F(1,75)=4.835$, $p<0.05$. Taking the current study into consideration, mastery experience was revealed to influence teacher efficacy belief. It also corroborates the study by TschannenMoran and Hoy (In press), which found that mastery experiences made the strongest contribution to teachers' efficacy for both novices and experienced teachers. The findings also provide strong support to Bandura [23], who regarded mastery experiences as the most powerful influence on teachers' self-efficacy beliefs. This suggests that the more mastery experience one has, the stronger the basis for judging one's capabilities. Preservice teachers who have sufficient mastery experience are likely to be subjected to less distress, contributing to an increase in teacher selfefficacy.

Even though the degree of influence is quite low, it still does not downplay that mastery experience influences teacher efficacy. The explanation for the low degree of influence may be that given the prevalent characteristics of accounting teachers in the field, a high or low level of efficacy beliefs of preservice accounting teachers in implementation is likely to emerge from other sources of efficacy beliefs, such as vicarious experiences, social persuasions, and physiological states other than mastery experiences [27]. It may also be due to the fact that, since the current study did not consider the influence of the other sources cited (vicarious experience, verbal and social persuasion, and physiological and affective states), there was no basis of comparison to determine the highest source of influence. This finding contradicts the theoretical argument of self-efficacy theory, where mastery experiences are argued to have a very high predictive power of selfefficacy.

\section{Conclusions}

Preservice accounting teachers' high level of self-efficacy in teaching cost accounting indicates that they had high capabilities in getting their students to follow classroom rules, fostering creativity among their students, and improving their students' self-confidence through motivation and encouragement. However, their level of competence higher in classroom management as compared to instructional strategies and student engagement techniques suggests that the curriculum implementors over emphasise classroom engagement techniques more than they do for instructional strategies and student engagement. Also, preservice accounting teachers might be more comfortable developing classroom management competencies more than instructional strategies and student engagement.

Preservice accounting teachers' mastery experience resulted in their high self-efficacy. This suggests that the preservice accounting teachers who rated themselves highly efficacious were those with high academic achievement in cost accounting. Again, their high mastery experience is 
likely to lead to effective teaching since mastery experience directly improves internal competency related to content knowledge. Impliedly, high mastery experience, which translates into higher self-efficacy, will contribute to proficient teaching performance in the future.

\section{Implications}

The policy implication of this study is the need to strive to recruit people with superior academic ability, especially in the teaching subject. The understanding obtained from the study is that mastery knowledge influences one's self-efficacy in teaching; therefore, teacher recruitment should consider the specific scores or grades obtained by potential teachers before engaging their services.

\section{Data Availability}

The data on which the conclusions of the study are based are embedded in the manuscript.

\section{Conflicts of Interest}

The authors declare that they have no conflicts of interest.

\section{Acknowledgments}

The authors acknowledge Prof. Mohammed Anokye Adam's support to proofread the manuscript to shape it to its current state.

\section{References}

[1] N. I. Edeh, C. A. Obi, and E. O. Ugwoke, "The strategies required for improving the teaching of cost accounting in colleges of education in south-east, nigeria," Library Philosophy and Practice, vol. 2399, pp. 1-49, 2019.

[2] S. Lamb and S. Fullarton, "Classroom and school factors affecting mathematics achievement: a comparative study of Australia and the United States using TIMSS," Australian Journal of Education, vol. 46, no. 2, pp. 154-171, 2002.

[3] C. A. Mege, Influence of School Environmental Factors on Teaching-Learning Process in Public Primary Schools in Lower Nyokal Division, Homa-Bay District, Kenya, (Doctoral Dissertation), University of Nairobi, Nairobi, Kenya, 2014.

[4] T. T. Tran, "Factors affecting teaching and learning English in Vietnamese universities," The Internet Journal Language, Culture and Society, vol. 38, no. 1, pp. 138-145, 2013.

[5] N. Börü, "The factors affecting teacher-motivation," International Journal of Instruction, vol. 11, no. 4, pp. 761-776, 2018.

[6] M. Nadeem, M. S. Rana, A. H. Lone, S. Maqbool, K. Naz, and A. Akhtar, "Teacher's competencies and factors affecting the performance of female teachers in Bahawalpur (southern Punjab) Pakistan," International Journal of Business and Social Science, vol. 2, no. 19, pp. 456-469, 2011.

[7] O. O. Olagbaju, "Teacher-related classroom factors as predictors of students' achievement in english grammar in gambian secondary schools," Educational Research International, vol. 2020, 2020.

[8] N. Sultana, M. I. Yousuf, M. N. Ud Din, and S. Rehman, "The higher the quality of teaching the higher the quality of education," Contemporary Issues In Education Research, vol. 2, no. 3, pp. 59-64, 2009.

[9] J. W. Hur, D. Shannon, and S. Wolf, "An investigation of relationships between internal and external factors affecting technology integration in classrooms," Journal of Digital Learning in Teacher Education, vol. 32, no. 3, pp. 105-114, 2016.

[10] K. Izci, "Internal and external factors affecting teachers' adoption of formative assessment to support learning," Online Submission, vol. 10, no. 8, pp. 2774-2781, 2016.

[11] J. S. Jones, The External and Internal Educational Factors that Contribute to Student Achievement and Self-Perceptions of Urban Middle School Title I Students (Theses and Dissertations), Rowan University, NJ, USA, 2012.

[12] C. S. S. N. Pavione, B. C. Avelino, and J. R. de Souza Francisco, "Factors that influence the teaching-learning process from the perspective of accountancy students: analysis at a higher education institution in minas gerais," Revista de Educação e Pesquisa em Contabilidade, vol. 10, no. 2, pp. 456-476, 2016.

[13] L. A. Ruble and J. H. McGrew, "Teacher internal and external factors," in COMPASS and Implementation Science. SpringerBriefs in Psychology, Springer, Cham, NY, USA, 2015.

[14] C. Achurra and L. Villardón, "Teacher' self-efficacy and student learning," European Journal of Social \& Behavioural Sciences, vol. 2, no. 1, pp. 367-383, 2013.

[15] L. Burney, V. Zascavage, and M. Matherly, "Advancing accounting research of teaching efficacy: developing a scale to measure student attitudes toward active learning experiences," Leadership and Research in Education, vol. 4, no. 1, pp. 55-76, 2017.

[16] C. M. Kuusinen, The Meaning and Measure of Teacher SelfEfficacy for Effective Classroom Teaching Practices (Doctoral Dissertation), University of Michigan, Michigan, USA, 2016.

[17] M. L. Ferreira, Managing Change: The Measurement of Teacher Self-Efficacy in Technologyenhanced Student-Centred Learning Environments, Master's thesis, Royal Roads University, 2013, https://dspace.royalroads.ca/bitstream/handle/ 10170/639/ferreira_lucy.pdf?sequence $=1$.

[18] H. Jeon, "Teacher efficacy research in a global context," International Handbook of Teacher Quality and Policy, vol. 1, no. 1, pp. 414-429, 2017.

[19] S. Tweed, Technology Implementation: Teacher Age, Experience, Self-Efficacy and Professional Development as Related Classroom Technology Integration (Unpublished Doctoral Thesis), East Tennessee State University, Tennessee, TN, USA, 2013.

[20] M. Tschannen-Moran and A. W. Hoy, "The differential antecedents of self-efficacy beliefs of novice and experienced teachers," Teaching and Teacher Education, vol. 23, no. 6, pp. 944-956, 2007.

[21] A. Bandura, Self-efficacy in Changing Societies, Cambridge University Press, Cambridge, England, 1995.

[22] A. Bandura, "The explanatory and predictive scope of selfefficacy theory," Journal of Social and Clinical Psychology, vol. 4, no. 3, pp. 359-373, 1986.

[23] A. Bandura, Self-efficacy: The Exercise of Control, W. H. Freeman and Company, New York, NY, USA, 1997.

[24] T. H. Yates, Teachers' Self-Efficacy in Mathematics and Teaching Mathematics, Instructional Practices, and the Mississippi Curriculum Test, for Mathematics in Grades 3-5, Unpublished $\mathrm{PhD}$ Dissertation, University of Southern Mississippi, Hattiesburg, MS, USA, 2014.

[25] M. Pantziara and G. N. Philippou, "Students' motivation in the mathematics classroom. Revealing causes and 
consequences," International Journal of Science and Mathematics Education, vol. 13, no. 2, pp. 385-411, 2015.

[26] R. Blonder, N. Benny, and M. G. Jones, "Teaching self-efficacy of science teachers," in The Role of Science Teachers' Beliefs in International Classrooms, pp. 1-15, Brill Sense, Leiden, The Netherlands, 2014.

[27] A. H. Ntarmah, M. K. Gyan, S. Gyedu, and E. Cobbinah, "The predictive power of sources of teacher efficacy beliefs on Economics teachers' efficacy beliefs in the implementation of senior high school economics curriculum," International Journal of Advance Research and Innovative Ideas in Education, vol. 5, no. 3, pp. 1686-1699, 2019.

[28] J. A. Ross, J. Bradley Cousins, and T. Gadalla, "Within-teacher predictors of teacher efficacy," Teaching and Teacher Education, vol. 12, no. 4, pp. 385-400, 1996.

[29] J. T. Kwarteng, Status of Accounting Curriculum Implementation: A Concerns-Based Adoption Model Assessment in Ashanti and Central Regions, Unpublished Master's Thesis, University of Cape Coast, Cape Coast, Ghana, 2009.

[30] P. Boateng, F. O. Sekyere, and F. O. Sekyere, "Exploring inservice teachers' self-efficacy in the kindergarten classrooms in Ghana," International Journal of Instruction, vol. 11, no. 1, pp. 239-254, 2018.

[31] C. Cobbold and P. Boateng, "How confident are kindergarten teachers in their ability to keep order in the classroom? A study of teacher efficacy in classroom management," Journal of Education and Practice, vol. 7, no. 36, pp. 181-197, 2016.

[32] D. Siaw-Marfo, Teacher Efficacy in the Teaching Senior High School Social Studies in the Greater Accra Region of Ghana (Doctoral Dissertation), University of Cape Coast, Cape Coast, Ghana, 2011.

[33] M. Tschannen-Moran and A. W. Hoy, "Teacher efficacy: capturing an elusive construct," Teaching and Teacher Education, vol. 17, no. 7, pp. 783-805, 2001.

[34] C. Cobbold and P. Boateng, "Exploring the instructional practices efficacy beliefs of kindergarten teachers in the Kumasi metropolis of Ghana," Journal of Developing Country Studies, vol. 5, no. 6, pp. 173-187, 2015.

[35] A. F. Al-Alwan and A. M. Mahasneh, "Teachers' self-efficacy as determinant of students' attitudes toward school: a study at the school level," Review of European Studies, vol. 6, no. 1, pp. 171-185, 2014.

[36] J. L. Blazevski, Teacher Efficacy for Supporting Student Motivation (Doctoral Dissertation), University of Michigan, MI, USA, 2006.

[37] K. Caraway, C. M. Tucker, W. M. Reinke, and C. Hall, "Selfefficacy, goal orientation, and fear of failure as predictors of school engagement in high school students," Psychology in the Schools, vol. 40, no. 4, pp. 417-427, 2003.

[38] A. Bandura, "Perceived self-efficacy in cognitive development and functioning," Educational Psychologist, vol. 28, no. 2, pp. 117-148, 1993.

[39] E. A. Linnenbrink, "The dilemma of performance-approach goals: the use of multiple goal contexts to promote students' motivation and learning," Journal of Educational Psychology, vol. 97, no. 2, pp. 197-213, 2005.

[40] F. Pajares and L. Graham, "Self-efficacy, motivation constructs, and mathematics performance of entering middle school students," Contemporary Educational Psychology, vol. 24, no. 2, pp. 124-139, 1999.

[41] F. Pajares and E. L. Usher, "Self-efficacy, motivation, and achievement in school from the perspective of reciprocal determinism," Advances in Motivation and Achievement, vol. 15, no. 2, pp. 391-423, 2008.
[42] P. R. Pintrich and E. V. De Groot, "Motivational and selfregulated learning components of classroom academic performance," Journal of Educational Psychology, vol. 82, no. 1, pp. 33-40, 1990.

[43] T. J. Cleary and B. J. Zimmerman, “A cyclical self-regulatory account of student engagement: theoretical foundations and applications," in Handbook of Research on Student Engagement, pp. 237-257, Springer, Boston, MA, USA, 2012.

[44] H. J. Choi, "Self-efficacy for self-regulated learning, academic self-efficacy, and internet self-efficacy in web-based instruction," Educational Technology Research \& Development, vol. 48 , no. 2 , pp. $5-17,2000$.

[45] F. Pajares, M. D. Miller, and M. J. Johnson, "Gender differences in writing self-beliefs of elementary school students," Journal of Educational Psychology, vol. 91, no. 1, pp. 50-61, 1999.

[46] F. Pajares and G. Valiante, "Self-efficacy beliefs and motivation in writing development," in Handbook of Writing Research, C. A. MacArthur, S. Graham, and J. Fitzgerald, Eds., pp. 158-170, The Guilford Press, New York, NY, USA, 2006.

[47] H. Wong, The First Day of School, Harry K. Wong Publications, New York, NY, USA, 2009.

[48] G. Dustova and S. Cotton, "Classroom management strategies," Career and Technical Education Journal, vol. 3, no. 2, pp. 32-42, 2015.

[49] R. J. Marzano, J. S. Marzano, and D. Pickering, Classroom Management that Works: Research-Based Strategies for Every Teacher, ASCD, Alexandria, VA, USA, 2003.

[50] K. P. Allen, "Classroom management, bullying, and teacher practices," Professional Educator, vol. 34, no. 1, pp. 1-19, 2010.

[51] E. Jepson and S. Forrest, "Individual contributory factors in teacher stress: the role of achievement striving and occupational commitment," British Journal of Educational Psychology, vol. 76, no. 1, pp. 183-197, 2006.

[52] W. K. Hoy and A. E. Woolfolk, "Teachers' sense of efficacy and the organizational health of schools," The Elementary School Journal, vol. 93, no. 4, pp. 355-372, 1993.

[53] R. Williams, "Gaining a degree: the effect on teacher selfefficacy and emotions," Professional Development in Education, vol. 35, no. 4, pp. 601-612, 2009.

[54] C. T. Chacón, "Teachers' perceived efficacy among English as a foreign language teachers in middle schools in Venezuela," Teaching and Teacher Education, vol. 21, no. 3, pp. 257-272, 2005.

[55] O. Gürbüztürk and S. N. Şad, "Student teachers? Beliefs about teaching and their sense of self-efficacy: a descriptive and comparative analysis," Inönü Üniversitesi Eğitim Fakültesi Dergisi, vol. 10, no. 3, pp. 201-226, 2009.

[56] S. Shaukat and H. M. Iqbal, "Teacher self-efficacy as a function of student engagement, instructional strategies and classroom management," Pakistan Journal of Social and Clinical Psychology, vol. 9, no. 3, pp. 82-85, 2012.

[57] D. Pendergast, S. Garvis, and J. Keogh, "Pre-service studentteacher self-efficacy beliefs: an insight into the making of teachers," Australian Journal of Teacher Education, vol. 36, no. 12, pp. 4-13, 2011.

[58] A. Sevimel and G. Subasi, "The factors affecting teacher efficacy perceptions of Turkish pre-service English language teachers," The Journal of Language Learning and Teaching, vol. 8, no. 1, pp. 1-17, 2018.

[59] F. K. Sarfo, F. Amankwah, F. K. Sam, and D. Konin, “Teachers' self-efficacy beliefs: the relationship between gender and instructional strategies, classroom management and student 
engagement," Ghana Journal of Development Studies, vol. 12, no. 1-2, pp. 19-32, 2015.

[60] R. M. Klassen and M. M. Chiu, "Effects on teachers' selfefficacy and job satisfaction: teacher gender, years of experience, and job stress," Journal of Educational Psychology, vol. 102, no. 3, pp. 741-756, 2010.

[61] J. D. Yiboe, Pre-service Management Teachers' Perceived Level of Efficacy Beliefs in Teaching, Unpublished masters thesis, University of Cape Coast, Cape Coast, Ghana, 2019.

[62] R. Sak, "Comparison of self-efficacy between male and female pre-service early childhood teachers," Early Child Development and Care, vol. 185, no. 10, pp. 1629-1640, 2015.

[63] S. R. Mcneely and N. T. Mertz, "Cognitive constructs of preservice teachers: research on how student teachers think about teaching," in Proceedings of the Annual Meeting of the American Educational Research Association, Boston, MA, USA, April 1990.

[64] W. K. Wah, "Sources of influence on teacher self-efficacy among pre-service teachers," in Seminar Penyelidikan Pendidikan Institut Perguruan Batu Lintang 2007, 2007, https://www.ipbl.edu.my/bm/penyelidikan/seminarpapers/ 2007/Edpsychology/wongannaIPIPfp. pdf.

[65] T. Wangeri and H. Otanga, "Sources of personal teachers' efficacy and influence on teaching methods among teachers in primary schools in Coast Province, Kenya," Global Journal of Interdisciplinary Social Sciences, vol. 3, no. 3, pp. 190-195, 2014.

[66] G. Joët, E. L. Usher, and P. Bressoux, "Sources of self-efficacy: an investigation of elementary school students in France," Journal of Educational Psychology, vol. 103, no. 3, pp. 649-666, 2011.

[67] A. Arslan, "The mediating role of prospective teachers' teaching self-efficacy between self-efficacy sources and attitude towards teaching profession," International Journal of Educational Methodology, vol. 5, no. 1, pp. 87-96, 2019.

[68] U. Farooq, What is census method of data collection, advantages and disadvantages?, https://www.studylecturenotes. $\mathrm{com} /$ social-research-methodology/whatis-census-methodof-data-collection advantages -disadvantages, 2020.

[69] E. L. Usher and F. Pajares, "Sources of self-efficacy in mathematics: a validation study," Contemporary Educational Psychology, vol. 34, no. 1, pp. 89-101, 2009.

[70] J. Fraenkel and N. Wallen, How to Design and Evaluate Research in Education, McGraw-Hill, NY, USA, 4th edition, 2000.

[71] M. Abington-Cooper, An Evaluation of the LSU Agricultural Center's Agricultural Leadership Development Programme, 1988-2004, (Unpublished doctoral dissertation), Northeast Louisiana University, Louisiana, USA, 2005.

[72] S. C. Tsiang, "The rationale of the mean-standard deviation analysis, skewness preference, and the demand for money," The American Economic Review, vol. 62, no. 3, pp. 354-371, 1972.

[73] P. H. Baker, "Managing student behavior: how ready are teachers to meet the challenge?" American Secondary Education, vol. 33, no. 2, pp. 51-64, 2005.

[74] J. P. Stichter, T. J. Lewis, T. A. Whittaker, M. Richter, N. W. Johnson, and R. P. Trussell, "Assessing teacher use of opportunities to respond and effective classroom management strategies," Journal of Positive Behavior Interventions, vol. 11, no. 2, pp. 68-81, 2009.

[75] A. Epstein and G. L. Willhite, "Teacher efficacy in an early childhood professional development school," International
Electronic Journal of Environmental Education, vol. 7, no. 2, pp. 189-198, 2015.

[76] M. Tschannen-Moran, A. W. Hoy, and W. K. Hoy, "Teacher efficacy: its meaning and measure," Review of Educational Research, vol. 68, no. 2, pp. 202-248, 1998.

[77] C. A. Mertler, Preservice versus In-Service Teachers' Assessment Literacy: Does Classroom Experience Make a Difference? Pyrczak, Los Angeles, CA, USA, 2004.

[78] H. Y. Cheung, "Teacher efficacy: a comparative study of Hong Kong and Shanghai primary in-service teachers," Australian Educational Researcher, vol. 35, no. 1, pp. 103-123, 2008.

[79] M. Tschannen-Moran and P. McMaster, "Sources of self-efficacy: four professional development formats and their relationship to self-efficacy and implementation of a new teaching strategy," The Elementary School Journal, vol. 110, no. 2, pp. 228-245, 2009. 